\title{
Treatment of Hepatitis B Virus-Associated Nephropathy
}

\author{
Usama Elewa ${ }^{a}$ Ana Maria Sandri b ${ }^{\text {W. Ray Kim }}{ }^{c}$ Fernando C. Fervenza ${ }^{d}$ \\ ${ }^{a}$ New Kasr Al-Aini Teaching Hospital, Cairo University, Cairo, Egypt; ${ }^{b}$ Division of Infectious Diseases, Hospital \\ São Lucas da PUCRS, Porto Alegre, Brazil; Divisions of ${ }^{\mathrm{C}}$ Gastroenterology, and ${ }^{\mathrm{d}}$ Nephrology and Hypertension, \\ Mayo Clinic, Rochester, Minn., USA
}

\section{Key Words}

Hepatitis B virus • Nephropathy • Antiviral therapy •

Immunosuppressive therapy

\begin{abstract}
Epidemiological studies have shown a relationship between hepatitis B virus (HBV) infection and development of proteinuria in some patients (most commonly children), with a predominance for male gender and histological findings of membranous nephropathy on renal biopsy. The presence of immune complexes in the kidney suggests an immune complex basis for the disease, but a direct relation between HBV and membranous nephropathy (or other types of glomerular diseases) remains to be proven. Clearance of HBV antigens, either spontaneous or following antiviral treatments results in improvement in proteinuria. Thus, prompt recognition and specific antiviral treatment are critical in managing patients with HBV and renal involvement. The present review focuses on treatment of HBV with special emphasis given to antiviral therapies, its complications, and dosing in patients with $\mathrm{HBV}$-associated kidney disease.
\end{abstract}

Copyright $\odot 2011$ S. Karger AG, Basel

\section{KARGER}

Fax +41613061234 E-Mail karger@karger.ch www.karger.com

\section{Introduction}

Approximately one third of the world's population has serological evidence of past or present infection with hepatitis $\mathrm{B}$ virus (HBV), and 350 million people are chronically infected, making it one of the most common human pathogens $[1,2]$. The spectrum of disease and natural history of chronic HBV infection is diverse and variable, ranging from a low viremic inactive carrier state to progressive chronic hepatitis, which may evolve to cirrhosis and hepatocellular carcinoma.

Renal involvement is among its most common extrahepatic manifestations and usually manifests in the form of immune complex mediated glomerulopathy, such as membranoproliferative glomerulonephritis [3-5], focal segmental glomerulosclerosis, minimal change disease $[6,7]$, lupus nephritis $[8,9]$, and IgA nephropathy $[10,11]$. However, the most common association is with membranous nephropathy $(\mathrm{MN})$, especially in children, and it is in this regard that the term HBV-associated nephropathy is most commonly used. However, with exception of MN, it is likely that the reports of other forms of glomerular disease in patients with HBV reflect mainly incidental findings $[6,12-19]$. 
Table 1. Phases of hepatitis B infection

\begin{tabular}{llll}
\hline Phase & HBeAg & ALT & HBV DNA \\
\hline Immune tolerance & + & normal & very high \\
HBeAg-positive hepatitis & + & abnormal high \\
Inactive carrier & - & normal & low/undetectable \\
HBeAg-negative hepatitis & - & abnormal high \\
\hline
\end{tabular}

An example of the potential incidental findings can be given regarding IgA nephropathy. Lai et al. [11, 20, 21] examined the ability of HBV antigenemia in inducing IgA nephropathy in patients with IgA nephropathy with no previous history of liver diseases and normal liver function tests. All were $\mathrm{HBsAg}$ and anti-HBcAg positive with high titers. Immunoperoxidase studies using monospecific polyclonal antibodies revealed $\mathrm{HBcAg}$ and HBsAg in the nuclei and cytoplasm of glomerular mesangial cells in the majority of patients. The authors concluded that immune complexes involving $\mathrm{HBcAg}$ and HBsAg may induce IgA nephropathy in persons who carry HBV. It is, however, unclear whether IgA nephropathy is a 'complication' of HBV infection or merely a coincidental association in countries where both $\mathrm{HBV}$ and IgA nephropathy are common, e.g. China, where nationwide cross-sectional seroepidemiological study in the 1990s showed that approximately $60 \%$ of the population had a history of $\mathrm{HBV}$ infection, and $9.8 \%$ of persons were chronically infected with HBV [22], and at the same time, IgA nephropathy is the most common form of a glomerular disease in this population [23]. The pathogenesis of $\mathrm{HBV}$-associated nephropathy, including potential immunopathogenetic mechanisms, biosocial background and genetic factors has been the subject of a recent review [24]. The diagnosis of HBV-mediated glomerular disease requires detection of the virus in the blood and the exclusion of other causes of glomerular diseases.

\section{Natural History}

Subjects with chronic HBV infection can be divided into two groups: $\mathrm{HBeAg}$ positive and negative (table 1). In most cases, chronic HBV infection begins with positive $\mathrm{HBeAg}$, which classically is a marker of active viral replication. Many HBeAg-positive children and adolescents have normal liver enzymes despite high levels of HBV DNA (often called 'immune tolerant phase'). Over time, immune recognition of HBV proteins expressed on hepatocytes leads to active hepatitis (HBeAg-positive hepatitis phase). Continued immune maturation often results in control (but not elimination) of the virus, as indicated by loss of HBeAg and acquisition of anti-HBe antibody (inactive carrier phase). Not all HBeAg-negative patients have inactive disease since some manifest abnormal liver enzymes and high levels of HBV DNA. This is thought to be a result of immune escape as a result of certain mutations of the virus ('pre-core').

\section{Epidemiology of HBV-Associated Nephropathy}

The reported prevalence of HBV-associated nephropathy, particularly $\mathrm{MN}$, closely parallels the geographic patterns of prevalence of HBV (table 2). In children with HBV-associated nephropathy, it would appear that horizontal transmission of $\mathrm{HBV}$ is the predominant mode of transmission in most regions [25]. The rarity of HBVassociated nephropathy in developed countries such as the USA and Europe probably reflects the rarity of HBV infection, particularly in children. In the USA, HBV-related $\mathrm{MN}$ is most frequently seen in African-Americans [26]. In developed countries, HBV-associated nephropathy is frequently seen in adults who are high-risk groups such as intravenous drug abusers and in dialysis patients [24]. Introduction of HBV immunization in several endemic regions for $\mathrm{HBV}$ infection was one of the principle factors in lowering the incidence of HBV-associated nephropathy [24].

Another condition that has also been affected by HBV immunization is classic polyarteritis nodosa (PAN). Hepatitis $\mathrm{B}$-associated PAN is a typical form of PAN whose pathogenesis has been attributed to immune complex deposition with antigen excess [27]. By concept, PAN is characterized by arteritis in medium-sized and small arteries without involvement of smaller vessels (e.g. without glomerulonephritis) [28]. PAN also differs from other vasculitis involving the kidney (e.g. Wegener and microscopic polyangiitis) in that antineutrophil cytoplasmic antibodies (ANCA) are not detected, relapses are rare, never occur once viral replication has been stopped and/ or seroconversion occurs. Importantly, the frequency of hepatitis B-associated PAN has decreased due to widespread HBV immunization [27].

\section{Clinical Course and Prognosis}

The natural history of HBV-associated MN is not well defined. In children, $\mathrm{HBV}$-associated $\mathrm{MN}$ has a favorable 
Table 2. Worldwide distribution of HBV infection [24]

\begin{tabular}{llll}
\hline & Endemic status & & \\
\cline { 2 - 4 } & low & intermediate & high \\
\hline Prevalence & & \\
$\begin{array}{l}\text { Chronic infection } \\
\text { Total infection }\end{array}$ & $<2 \%$ & $2-7 \%$ & $8-15 \%$ \\
Distribution & $<20 \%$ & $20-60 \%$ & $>60 \%$ \\
& North America & Eastern Europe & Southeast Asia \\
& Western Europe & Southern Europe & China \\
& Australia & Soviet Union & Philippines? \\
& New Zealand & Central Asia & Indonesia \\
& South America (Southern) & Japan & Middle East \\
& & Israel & Africa \\
& & South America (Northern) & Amazon Basin \\
& & Pacific Islands \\
& & & Arctic (Inuit) \\
\hline
\end{tabular}

prognosis with high spontaneous remission rate, although some patients may remain proteinuric for 12 months or longer $[18,29-33]$. In adults, however, HBVassociated $\mathrm{MN}$ is usually progressive with resolution of proteinuria being relatively uncommon [18, 29, 31, 34, 35]. Patients with nephrotic syndrome and abnormal liver function tests have an even worse prognosis with $>50 \%$ progressing to ESRD in the short term [36]. Development of anti-HBeAg antibodies and HBeAg clearance are associated with remission of proteinuria $[14,30]$. On the other hand, patients who do not clear the virus usually develop progressive renal failure $[18,29,37]$.

\section{Treatment}

\section{Antiviral Therapy}

In the US, 7 agents have been approved by FDA for use in the treatment of adults with HBV. They all decrease HBV DNA levels. These agents are interferon- $\alpha$ (conventional interferon- $\alpha_{2} b$ and longer-acting peginterferon$\alpha_{2} \mathrm{a}$ ), or nucleoside/nucleotide analogues (lamivudine, adefovir, entecavir, tenofovir, and telbivudine). Emtricitabine is available in Europe (in the US it is approved for HIV only).

The efficacy of these drugs has been assessed in RCT at 1 year (2 years with telbivudine and tenofovir). Longerterm follow-up (up to 5 years) is available for lamivudine, adefovir, entecavir, telbivudine and tenofovir in patient subgroups [1]. Treatment of patients with HBV infection and glomerulonephritis should be conducted using a multidisciplinary approach according to standard clini- cal practice guidelines for HBV infection [1, 2], and with the understanding that the bulk of the available data regarding the use of anti-viral agents pertains to patients with HBV infection but not necessarily with renal involvement.

Antiviral agents may be used as monotherapy or in combination. Interferon use has a defined, self-limited course; in contrast, therapy with nucleoside or nucleotide analogues can be used long-term [2]. As it will be discussed shortly, each category of treatment has unique advantages and risks associated with administration of the drug. Health care providers should discuss with the patients the risks and benefits of the different treatment options in order to arrive at the best possible decisions.

A number of randomized control trials in both $\mathrm{HBeAg}$ positive and -negative patients have shown that either monotherapy with peguilated-IFN or in combination with lamivudine is more effective than lamivudine alone at reducing HBV DNA, and in HBeAg-positive patients, inducing $\mathrm{HBeAg}$ seroconversion [38, 39]. Combined therapy, however, was not better than pegylated-IFN monotherapy in achieving suppression of HBV off therapy $[38,39]$. Patients with kidney disease (serum creatinine $>1.5 \mathrm{mg} / \mathrm{dl}$ ) were excluded from these studies. There is only one study on the use IFN- $\alpha$ in 40 Chinese children with HBV-mediated MN who showed no response to corticosteroid treatment [40]. Twenty patients were randomized to IFN- $\alpha$ (group 1) three times a week for 12 months, and 20 to supportive treatment only (group 2) [40]. HBeAg and HBsAg were positive in all patients. At the end of the 3rd month of treatment, all patients in group 1 were free of proteinuria. In contrast, 10 patients $(50 \%)$ in 
Table 3. Dosage adjustment of drugs for hepatitis B according to kidney function

\begin{tabular}{|c|c|c|c|c|}
\hline & $\mathrm{CrCl}>50 \mathrm{ml} / \mathrm{min}$ & $\mathrm{CrCl} 30-<50 \mathrm{ml} / \mathrm{min}$ & $\mathrm{CrCl} 10-<30 \mathrm{ml} / \mathrm{min}$ & $\mathrm{CrCl}<10 \mathrm{ml} / \mathrm{min}$ \\
\hline Lamivudine & 100 mg p.o. q.d. & $\begin{array}{l}100 \mathrm{mg} \text { first dose then } \\
50 \mathrm{mg} \text { p.o. q.d. }\end{array}$ & $\begin{array}{l}100 \mathrm{mg} \text { first dose then } \\
25 \mathrm{mg} \text { p.o. q.d. }\end{array}$ & $\begin{array}{l}35 \mathrm{mg} \text { first dose then } 15 \mathrm{mg} \\
\text { p.o. q.d. }{ }^{\mathrm{a}}\end{array}$ \\
\hline Adefovir & 10 mg p.o. q.d. & 10 mg p.o. every 48 h & 10 mg p.o. every $72 \mathrm{~h}$ & no dosing recommended \\
\hline Entecavir & 0.5 mg p.o. q.d. & 0.25 mg p.o. q.d. & 0.15 mg p.o. q.d. & 0.05 mg p.o. q.d. \\
\hline $\begin{array}{l}\text { Entecavir in lamivudine- } \\
\text { refractory patients }\end{array}$ & 1 mg p.o. q.d. & 0.5 mg p.o. q.d. & 0.3 mg p.o. q.d. & 0.1 mg p.o. q.d. \\
\hline Telbivudine & 600 mg p.o. q.d. & 600 mg p.o. every 48 h & 600 mg p.o. every $72 \mathrm{~h}$ & 600 mg p.o. every $96 \mathrm{~h}$ \\
\hline Tenofovir & 300 mg p.o. q.d. & 300 mg p.o. q.d every 48 h & $\begin{array}{l}300 \mathrm{mg} \text { p.o. q.d every } \\
72-96 \mathrm{~h}\end{array}$ & 300 mg p.o. once a week \\
\hline
\end{tabular}

a Lamivudine should be dosed at $35 \mathrm{mg}$ initially and then $10 \mathrm{mg}$ daily for patients with $\mathrm{CrCl}<15 \mathrm{ml} / \mathrm{min}$. Modified from Lau et al. [38] and Olsen and Brown [42].

group 2 had persistent heavy proteinuria. At the end of the 12th month, 8 patients (40\%) in group 2 still had persistent heavy proteinuria and 12 patients $(60 \%)$ had frequent relapses. The fact that children tend to improve regardless of treatment raises questions on the true efficacy of the therapy. On the other hand, 8 patients (40\%) in group 1 underwent $\mathrm{HBeAg}$ seroconversion between the 4th and 6th months and HBsAg seroconversion between the 10th and 12th months. HBeAg- seroconversion $(\mathrm{HBsAg}+)$ occurred in 4 patients, while 4 patients had no change in HBV serological markers (HBeAg+/HBsAg+). The remaining 4 patients had $\mathrm{HBeAg}-/ \mathrm{HBeAb}+$ $\mathrm{HBsAg}-/ \mathrm{HBsAb}-$ at the end of the 12th month. In contrast, none of the patients treated conservatively underwent seroconversion. On the other hand, in the only study to report on the effect of interferon- $\alpha_{2} b$ in 24 African children with $\mathrm{HBV}$-associated $\mathrm{MN}, 10$ of the children who completed 16 weeks of therapy (52.6\%) responded with clearance of HBeAg by 40 weeks [41]. None cleared HBsAg. Remission of proteinuria occurred in all responders, with $>90 \%$ of the patients either maintaining normal renal function or showing renal function improvement. HBV DNA levels decreased in this group. None of the 9 patients who did not clear HBeAg showed remission of proteinuria, while 2 developed progressive renal failure. In the control group, only $5 \%$ of the patients showed spontaneous clearance of HBeAg, and none had remission of proteinuria [41]. These studies support the notion that antiviral therapy is effective in inducing proteinuria remission and preserving renal function in patients with $\mathrm{HBV}$-associated MN.
An advantage of IFN- $\alpha$ is that it is given for a defined course (16-48 weeks), but requires subcutaneous injection and is associated with a number of side effects including influenza-like symptoms, hematologic abnormalities, depression, anorexia, diarrhea, dermatitis, alopecia, and increased infection rate. Treatment with IFN- $\alpha$ (conventional or pegylated) has the advantage of the absence of resistance as well as the potential for immune-mediated containment of HBV infection with an opportunity to obtain a long-term suppression of HBV off-treatment and a chance of HBsAg loss in a small number of patients who achieve and maintain undetectable HBV DNA. IFN- $\alpha$ is, however, contraindicated in patients with decompensated liver disease.

Nucleoside and nucleotide analogues are administered orally, are associated with more profound HBV DNA suppression than IFN- $\alpha$, and may be safely used in previous nonresponders to IFN- $\alpha$ therapy. Unfortunately, resurgence of HBV DNA levels occurs if the drug is prematurely discontinued or if resistance to the drug develops. All nucleoside and nucleotide analogues need dose adjustment in patients with kidney insufficiency (see table 3).

Data on lamivudine use in patients with kidney disease are limited to uncontrolled studies on small numbers of patients. It is administered once daily, typically at a dose of $100 \mathrm{mg}$, and is generally well tolerated and safe in long-term studies. Side effects, when they occur, are generally mild and include headache, nausea, and vomiting [42]. Tang et al. [43] treated $10 \mathrm{HBsAg-positive} \mathrm{pa-}$ tients with biopsy-proven $\mathrm{MN}$, elevated liver enzymes, 
and HBV DNA with lamivudine for 12 months (group 1), and compared their clinical course with a historical control group of 12 patients with HBV infection, elevated liver enzymes, and $\mathrm{MN}$ who had been followed in the prelamivudine era (group 2). At 6 months, lamivudine treatment was associated with significant reduction in proteinuria, increase in serum albumin, normalization of liver enzymes, and disappearance of circulating HBV DNA during the first year. Four (40\%) and $6(60 \%)$ patients went into complete remission of proteinuria $(<0.3$ g/day) at 6 and 12 months, respectively. In group 2, significant proteinuria persisted during the first year. One (8.3\%) and $3(25 \%)$ patients went into remission. Cumulative 3-year renal survival (using ESRD as primary end point) was $100 \%$ in group 1 and $58 \%$ in group $2(\mathrm{p}=$ 0.024 ). Lamivudine was well tolerated and not associated with any adverse events [43]. However, lamivudine dose needs to be adjusted according to the degree of kidney function [44]. More recently, Chuang et al. [45], reported on the case of a 22-year-old male with HBV, MN and nephrotic syndrome who had complete remission after lamivudine monotherapy. The significance of these data resides in the proof of the concept that HBV suppression by antiviral drugs leads to improved renal outcome, not necessarily that lamivudine is to be used in these patients. This is because lamivudine has a big disadvantage of being susceptible to resistant mutations. Due to the high incidence of resistance (14-20\% at 1 year and as high as $69 \%$ at 5 years), which essentially decreases the effectiveness of the drug, current guidelines recommendations consider lamivudine as a second agent. An additional factor when using lamivudine is the development of crossresistance with other nucleoside analogues (i.e. telbivudine and entecavir) [46].

Adefovir dipivoxil is a phosphonate nucleotide analog of adenosine, which competitively binds HBV DNA polymerase and serves as a chain terminator. Adefovir is used at a dose of $10 \mathrm{mg}$ daily and has been effective in the treatment of naive $\mathrm{HBeAg}$-positive and -negative patients, lamivudine-resistant patients, patients coinfected with $\mathrm{HIV}$, and in the postliver transplant setting [47-50]. Unfortunately, the inhibitory effect of adefovir in HBV viral replication is relatively weak and viral rebound occurs soon after treatment is stopped [51]. In addition, the development of resistance is increasingly recognized in patients treated with adefovir monotherapy long term [51]. Furthermore, the use of adefovir in patients with kidney disease has been limited by concern for potential nephrotoxicity. In animal studies, renal toxicity is characterized by tubular nephropathy and increase in serum creati- nine. These changes developed, however, at doses 3-8 times greater than the recommended dose for humans. Although patients with significant renal disease were excluded from the studies cited above, significant increases in creatinine were not seen on adefovir therapy at the dose of $10 \mathrm{mg}$ a day [52]. In addition, adefovir has been studied in 11 patients with lamivudine-resistant HBV status after kidney transplant, and found to be both safe and efficacious in this patient population [53]. The current guideline also relegates adefovir as a second tier drug because of its weak potency and potential concern for renal toxicity in comparison to newer agents such as tenofovir or entecavir.

Similarly, telbivudine is a potent antiviral drug that has been shown to be effective in suppressing HBV in both HBeAg-positive and -negative patients. Unfortunately, it is more prone to the development of resistant mutations than entecavir or tenofovir. It also has toxicity including myopathy and, when combined with interferon, peripheral neuropathy.

On the other hand, entecavir is a guanosine analog that inhibits HBV DNA polymerase at both the priming and elongating steps of DNA synthesis. It has been shown to be more effective than lamivudine in suppressing viral replication, in both $\mathrm{HBeAg}$-positive and -negative patients [54]. Recent data of HBeAg-positive patients treated with $0.5 \mathrm{mg}$ of entecavir showed better histologic improvement than those on lamivudine (72 vs. $62 \%)$ as well as higher clearance of HBV DNA levels (69 vs. $38 \%$ in the lamivudine group). HBeAg seroconversion rates, however, of $21 \%$ with entecavir and $18 \%$ with lamivudine were not significantly different [55]. Similar results have been obtained in HBeAg-negative patients treated with entecavir versus patients on lamivudine [56]. Resistance to entecavir is rare, but was seen in over $7 \%$ of the lamivudine-resistant patients treated with entecavir for 1 year, making it unlikely to be the drug of choice as a monotherapy in this situation. Entecavir appears to be safe in patients with kidney diseases but the dose needs to be adjusted in patients with impaired kidney function (see table 3).

In 2 recent randomized control trials, tenofovir has been shown superior to adefovir. In patients HBeAg positive, 48 weeks' treatment with tenofovir resulted in significantly higher proportions of patients with undetectable HBV DNA by PCR (76 vs. 13\%), normalization of liver enzymes (68 vs. $54 \%$ ), HBsAg loss (3 vs. $0 \%$ ) and HBeAg seroconversion (21 vs. $18 \%$ ) compared to treatment with adefovir [57]. In HBeAg-negative patients, 48-week-long treatment with tenofovir resulted in a sig- 
nificantly higher proportion of patients with undetectable HBV DNA (93 vs. 63\%) than adefovir and similar proportion of patients achieving liver enzymes normalization (76 vs. $77 \%$ ), or histologic response (72 vs. $69 \%$ ) [57]. Tenofovir resistance was not detected in any of the patients up to 96 weeks of treatment, but additional therapy with emtricitabine was given to some patients who remained viremic at week 72 . Tenofovir has been reported to cause Fanconi syndrome and kidney failure [58]. Despite the robust potency and resistance profile of tenofovir, some experts recommend avoiding tenofovir in patients with HBV-related renal involvement because of the potential for renal toxicity.

As stated before, the benefit of antiviral therapy in patients with HBV-mediated glomerular disease was demonstrated only with lamivudine so far. However, it is likely that HBV suppression via other, more modern agents such as entecavir and tenofovir, will benefit those patients as well. Nonetheless, well-designed and well-conducted randomized controlled trials are sorely needed to conclusively demonstrate a beneficial effect on renal outcomes in patients with HBV-mediated kidney disease undergoing antiviral therapy.

\section{Immunosuppressive Therapy in HBV-Associated Nephropathies}

\section{Corticosteroids}

Corticosteroid therapy has been used in some patients with HBV-associated nephropathy as a therapeutic trial for symptomatic relief of proteinuria. Lai et al. [59] investigated the therapeutic benefits and risks of a 6-month course of corticosteroid in 8 patients with $\mathrm{MN}$, positive $\mathrm{HBsAg}$, high titers of anti-HBcAg ( $\mathrm{HBeAg}$ positive in 4 patients) and normal liver enzymes. Nephrotic syndrome was present in 7 patients. The use of corticosteroid resulted in remission of the nephrotic syndrome in 3 patients, but proteinuria persisted in 5 patients. Transient liver impairment was observed in 3 patients. As result of the use of corticosteroid therapy, transient viral replication with increased serum concentration of $\mathrm{HBeAg}$ and HBV DNA were observed. Similar increase in viral replication was reported by Cadrobbi et al. [60] in a 3-year-old boy with chronic active HBV and MN treated with corticosteroids. Withdrawal of corticosteroid therapy resulted in resolution of HBV replication, while both glomerulonephritis and chronic hepatitis went into remission. In at least one patient with $\mathrm{HBV}$ and $\mathrm{MN}$ where renal biopsies were taken before and after corticosteroid therapy, this form of therapy was associated with progression of glomerulosclerosis on light microscopy, while electron microscopy showed virus-like particles $(40-50 \mathrm{~nm}$ in diameter) in the glomeruli only in the biopsy performed after corticosteroid therapy [61]. In this patient, corticosteroid therapy was associated with an increase in liver enzymes, as well as serum levels of $\mathrm{HBeAg}$, and HBV DNA, suggesting active viral replication. In one case of a patient with $\mathrm{HBV}$-associated MN withdrawal of immunosuppressive treatment resulted in progression to a crescentic glomerulonephritis [62]. The authors speculate that immunosuppressive therapy stimulated HBV replication, and withdrawal of immunosuppression led to a return of the patient's immune competence with the resulting development of a crescentic glomerulonephritis. The available evidence does not support use of corticosteroids in $\mathrm{HBV}$-associated MN; corticosteroids may in fact enhance viral replication and precipitate hepatic flares [36].

\section{Other Immunosuppressive Agents}

A beneficial effect of plasma exchange used in combination with antiviral agents and/or immunosuppressant agents has been reported in patients with $\mathrm{HBV}$-associated PAN $[63,64]$. Another agent that has been increasingly used in patients with autoimmune diseases including $\mathrm{MN}$ and ANCA-associated vasculitis is rituximab, a monoclonal antibody against the $\mathrm{CD} 20$ antigen present on B cells and approved by the FDA in 1997 for the treatment of relapsed or refractory non-Hodgkin's lymphoma and more recently for patients with rheumatoid arthritis $[65,66]$. However, a word of caution should be said about rituximab, since in patients with HBV, the use of rituximab has resulted in HBV viral reactivation, the severity of which has resulted in death in some patients [67-70]. Preemptive use of entecavir has enabled successful management of $\mathrm{HBV}$ reactivation, although mild to moderate hepatic flare can still occur [71]. Similarly, the use of cytotoxic agents [72] and of azathioprine and cyclosporine in patients undergoing transplantation (even in HBsAgnegative patients with past $\mathrm{HBV}$ infection) has resulted in reactivation of $\mathrm{HBV}$ and fatal acute hepatitis in some cases $[73,74]$.

\section{Conclusions}

In the past decade, the advance in anti-HBV therapy has revolutionized management of patients with this infection. In addition to registration trials that are mentioned in this review, a randomized trial has shown that 
anti-HBV therapy alters the 'hard' endpoints, such as progression of cirrhosis and development of hepatocellular carcinoma [75]. Nonetheless, there remain limitations to the current therapy: the realistic goal of HBV therapy remains suppression of the virus rather than eradication, thus requiring long-term therapy. This is associated with concerns about financial burden, patient adherence and resistant mutations as well as potential for toxicity when the HBV drugs are used long term.

Obviously, HBV infection does not uniformly lead to development of renal disease. Incidence, risk factors and the natural history of renal involvement among patients with HBV infection are poorly understood [42]. Cases of spontaneous remission and of remission associated with HBeAg seroconversion have been described (especially in younger patients). The heterogeneity of patients with HBV infection (e.g. degree of liver compromise, renal involvement, degree of renal insufficiency) illustrates the complexity in establishing treatment guidelines in these patients, including those with HBV-mediated kidney disease.

In our opinion, evidence to date suggests that antiviral therapy improves $\mathrm{HBV}$-associated MN. However, this conclusion is based on a paucity of available information and greatly inferred from results of treatment of HBV patients in general. Thus, there is a need for good quality prospective controlled studies to address the effects of these interventions in patients with HBV-associated glomerular diseases, particularly in children, so we can better define the most effective therapies for these patients. Similarly, antiviral therapy should be considered in patients with renal insufficiency, but its overall long-term effect in changing the outcome of HBV infection in these patients remains to be proven.

The choice of the specific agent (e.g. interferon vs. an oral antiviral) is dictated by the overall clinical picture and best conducted via a multidisciplinary approach. However, in patients with HBeAg-negative disease, a long-term oral nucleoside analogue such as entecavir or tenofovir would be reasonable. Attractive candidates for interferon treatment include young patients, $\mathrm{HBe} A g$ positive and with elevated liver enzymes. Naturally, the dosing of these antiviral agents must be adjusted to the degree of kidney function. Finally, immunization and appropriate screening programs are extremely important steps in the effort to eradicate HBV infections and reduce the incidence of HBV-associated kidney diseases.

\section{References}

1 Liver EAFTSOT: EASL Clinical Practice Guidelines: management of chronic hepatitis B. J Hepatol 2009;50:227-242.

2 Sorrell MF, Belongia EA, Costa J, Gareen IF, et al: National Institutes of Health Consensus Development Conference Statement: management of hepatitis B. Ann Intern Med 2009; 150:104-110.

-3 Abbas NA, Pitt MA, Green AT, Solomon LR: Successful treatment of hepatitis B virus (HBV)-associated membranoproliferative glomerulonephritis (MPGN) with alpha interferon. Nephrol Dial Transplant 1999;14: 1272-1275.

-4 Conjeevaram HS, Hoofnagle JH, Austin HA, Park Y, et al: Long-term outcome of hepatitis $B$ virus-related glomerulonephritis after therapy with interferon alfa. Gastroenterology 1995;109:540-546.

- 5 Lisker-Melman M, Webb D, Di Bisceglie AM, Kassianides C, et al: Glomerulonephritis caused by chronic hepatitis $\mathrm{B}$ virus infection: treatment with recombinant human alpha-interferon. Ann Intern Med 1989;111: 479-483.
6 Brzosko WJ, Krawczynski K, Nazarewicz T, Morzycka M, et al: Glomerulonephritis associated with hepatitis-B surface antigen immune complexes in children. Lancet 1974;2: 477-482.

7 Lai KN, Lai FM, Tam JS, Chow CB, et al: High prevalence of hepatitis B surface antigenaemia in nephrotic syndrome in Hong Kong. Ann Trop Paediatr 1989;9:45-48.

8 Lai KN, Lai FM, Lo S, Leung A: Is there a pathogenetic role of hepatitis B virus in lupus nephritis? Arch Pathol Lab Med 1987;111: $185-188$

9 Looi LM, Prathap K: Hepatitis B virus surface antigen in glomerular immune complex deposits of patients with systemic lupus erythematosus. Histopathology 1982;6:141-147.

10 Khaira A, Upadhyay BK, Sharma A, Das P, et al: Hepatitis B virus associated focal and segmental glomerular sclerosis: report of two cases and review of literature. Clin Exp Nephrol 2009;13:373-377.

11 Lai KN, Lai FM, Lo S, Ho CP, et al: IgA nephropathy associated with hepatitis B virus antigenemia. Nephron 1987;47:141-143.

$\checkmark 12$ Bhimma R, Coovadia HM, Adhikari M Hepatitis B virus-associated nephropathy in black South African children. Pediatr Nephrol (Berlin) 1998;12:479-484.
13 Bhimma R, Coovadia HM, Kramvis A, Adhikari $\mathrm{M}$, et al: $\mathrm{HBV}$ and proteinuria in relatives and contacts of children with hepatitis $B$ virus-associated membranous nephropathy. Kidney Int 1999;55:2440-2449.

14 Gilbert RD, Wiggelinkhuizen J: The clinical course of hepatitis B virus-associated nephropathy. Pediatr Nephrol (Berlin) 1994;8: $11-14$.

15 Seggie J, Nathoo K, Davies PG: Association of hepatitis B (HBs) antigenaemia and membranous glomerulonephritis in Zimbabwean children. Nephron 1984;38:115-119.

-16 Coovadia HM, Adhikari M, Morel-Maroger L: Clinico-pathological features of the nephrotic syndrome in South African children. Q J Med 1979;48:77-91.

-17 Takekoshi Y, Tanaka M, Shida N, Satake Y, et al: Strong association between membranous nephropathy and hepatitis-B surface antigenaemia in Japanese children. Lancet 1978; 2:1065-1068.

18 Lai KN, Lai FM, Chan KW, Chow CB, et al: The clinico-pathologic features of hepatitis B virus-associated glomerulonephritis. Q J Med 1987;63:323-333. 
-19 Slusarczyk J, Michalak T, Nazarewicz-de Mezer T, Krawczynski K, et al: Membranous glomerulopathy associated with hepatitis $\mathrm{B}$ core antigen immune complexes in children. Am J Pathol 1980;98:29-43.

20 Lai KN, Lai FM, Lo ST, Lam CW: IgA nephropathy and membranous nephropathy associated with hepatitis B surface antigenemia. Hum Pathol 1987; 18:411-414.

21 Lai KN, Lai FM, Tam JS: IgA nephropathy associated with chronic hepatitis B virus infection in adults: the pathogenetic role of HBsAG. J Pathol 1989;157:321-327.

22 Shen LP, Zhang Y, Wang F, Zhang S, et al: Epidemiological changes in hepatitis B prevalence in an entire population after 20 years of the universal HBV vaccination programme. Epidemiol Infect, Epub ahead of print.

-23 Zhou FD, Zhao MH, Zou WZ, Liu G, et al: The changing spectrum of primary glomerular diseases within 15 years: a survey of 3,331 patients in a single Chinese centre. Nephrol Dial Transplant 2009;24:870-876.

24 Bhimma R, Coovadia HM: Hepatitis B virusassociated nephropathy. Am J Nephrol 2004; 24:198-211.

-25 Lin CY: Hepatitis B virus-associated membraneous nephropathy: clinical features, immunological profiles and outcome. Nephron 1990;55:37-44.

-26 Hepatitis B surface antigenemia in North American children with membranous glomerulonephropathy. Southwest Pediatric Nephrology Study Group. J Pediatr 1985;106: 571-578.

-27 Guillevin L, Mahr A, Callard P, Godmer P, et al: Hepatitis B virus-associated polyarteritis nodosa: clinical characteristics, outcome, and impact of treatment in 115 patients. Medicine 2005;84:313-322.

-28 Jennette JC, Falk RJ, Andrassy K, Bacon PA, et al: Nomenclature of systemic vasculitides. Proposal of an international consensus conference. Arthritis Rheum 1994;37:187-192.

-29 Hsu HC, Lin GH, Chang MH, Chen CH: Association of hepatitis B surface (HBs) antigenemia and membranous nephropathy in children in Taiwan. Clin Nephrol 1983;20: 121-129.

-30 Ito H, Hattori S, Matusda I, Amamiya S, et al: Hepatitis B e antigen-mediated membranous glomerulonephritis. Correlation of ultrastructural changes with HBeAg in the serum and glomeruli. Lab Invest 1981;44:214-220.

-31 Kleinknecht C, Levy M, Peix A, Broyer M, et al: Membranous glomerulonephritis and hepatitis B surface antigen in children. J Pediatr 1979;95:946-952.

>32 Knecht GL, Chisari FV: Reversibility of hepatitis B virus-induced glomerulonephritis and chronic active hepatitis after spontaneous clearance of serum hepatitis B surface antigen. Gastroenterology 1978;75:11521156.
Takekoshi Y, Tochimaru H, Nagata Y, Itami $\mathrm{N}$ : Immunopathogenetic mechanisms of hepatitis B virus-related glomerulopathy. Kidney Int Suppl 1991;35:S34-S39.

34 Lai KN, Li PK, Lui SF, Au TC, et al: Membranous nephropathy related to hepatitis B virus in adults. N Engl J Med 1991;324:1457-1463.

35 Lai KN, Lai FM: Clinical features and the natural course of hepatitis B virus-related glomerulopathy in adults. Kidney Int Suppl 1991;35:S40-S45.

36 Appel G: Viral infections and the kidney: HIV, hepatitis B, and hepatitis C. Cleve Clin J Med 2007;74:353-360

37 Kohler PF, Cronin RE, Hammond WS, Olin $\mathrm{D}$, et al: Chronic membranous glomerulonephritis caused by hepatitis B antigen-antibody immune complexes. Ann Intern Med 1974;81:448-451.

38 Lau GK, Piratvisuth T, Luo KX, Marcellin P, et al: Peginterferon Alfa-2a, lamivudine, and the combination for $\mathrm{HBeAg}$-positive chronic hepatitis B. N Engl J Med 2005;352:26822695.

39 Marcellin P, Lau GK, Bonino F, Farci P, et al: Peginterferon alfa-2a alone, lamivudine alone, and the two in combination in patients with $\mathrm{HBeAg-negative} \mathrm{chronic} \mathrm{hepati-}$ tis B. N Engl J Med 2004;351:1206-1217.

40 Lin CY: Treatment of hepatitis B virus-associated membranous nephropathy with recombinant alpha-interferon. Kidney Int 1995;47:225-230.

41 Bhimma R, Coovadia HM, Kramvis A, Adhikari $\mathrm{M}$, et al: Treatment of hepatitis $\mathrm{B}$ virus-associated nephropathy in black children. Pediatr Nephrol (Berlin) 2002;17:393399.

42 Olsen SK, Brown RS Jr: Hepatitis B treatment: lessons for the nephrologist. Kidney Int 2006;70:1897-1904.

43 Tang S, Lai FM, Lui YH, Tang CS, et al: Lamivudine in hepatitis B-associated membranous nephropathy. Kidney Int 2005;68: 1750-1758.

44 Rostaing L, Henry S, Cisterne JM, Duffaut M, et al: Efficacy and safety of lamivudine on replication of recurrent hepatitis $\mathrm{B}$ after cadaveric renal transplantation. Transplantation 1997;64:1624-1627.

45 Chuang TW, Hung CH, Huang SC, Lee CM: Complete remission of nephrotic syndrome of hepatitis B virus-associated membranous glomerulopathy after lamivudine monotherapy. J Formos Med Assoc 2007; 106:869873.

46 Liaw YF, Leung NW, Chang TT, Guan R, et al: Effects of extended lamivudine therapy in Asian patients with chronic hepatitis B. Asia Hepatitis Lamivudine Study Group. Gastroenterology 2000;119:172-180.

47 Benhamou Y, Thibault V, Vig P, Calvez V, et al: Safety and efficacy of adefovir dipivoxil in patients infected with lamivudine-resistant hepatitis B and HIV-1. J Hepatol 2006;44: 62-67.
48 Herreros de Tejada Echanojauregui A, Moreno Planas JM, Rubio Gonzalez E, Portero Azorin F, et al: Adefovir dipivoxil therapy in liver transplant recipients with lamivudineresistant hepatitis B virus. Transplant Proc 2005;37:1507-1508.

49 Marcellin P, Chang TT, Lim SG, Tong MJ, et al: Adefovir dipivoxil for the treatment of hepatitis B e antigen-positive chronic hepatitis B. N Engl J Med 2003;348:808-816.

50 Perrillo R, Hann HW, Mutimer D, Willems $\mathrm{B}$, et al: Adefovir dipivoxil added to ongoing lamivudine in chronic hepatitis $B$ with YMDD mutant hepatitis B virus. Gastroenterology 2004;126:81-90.

-51 Hadziyannis SJ, Tassopoulos NC, Heathcote EJ, Chang TT, et al: Long-term therapy with adefovir dipivoxil for $\mathrm{HBeAg-negative}$ chronic hepatitis B. N Engl J Med 2005;352: 2673-2681.

52 Izzedine H, Hulot JS, Launay-Vacher V, Marcellini $\mathrm{P}$, et al: Renal safety of adefovir dipivoxil in patients with chronic hepatitis B: two double-blind, randomized, placebo-controlled studies. Kidney Int 2004;66:11531158.

53 Fontaine H, Vallet-Pichard A, Chaix ML, Currie G, et al: Efficacy and safety of adefovir dipivoxil in kidney recipients, hemodialysis patients, and patients with renal insufficiency. Transplantation 2005;80:10861092.

54 Lai CL, Rosmawati M, Lao J, Van Vlierberghe $\mathrm{H}$, et al: Entecavir is superior to lamivudine in reducing hepatitis $\mathrm{B}$ virus DNA in patients with chronic hepatitis B infection. Gastroenterology 2002;123:1831-1838.

55 Chang TT, Gish RG, de Man R, Gadano A, et al: A comparison of entecavir and lamivudine for HBeAg-positive chronic hepatitis B. N Engl J Med 2006;354:1001-1010.

56 Lai CL, Shouval D, Lok AS, Chang TT, et al: Entecavir versus lamivudine for patients with $\mathrm{HBeAg}$-negative chronic hepatitis B. N Engl J Med 2006;354:1011-1020.

57 Marcellin P, Heathcote EJ, Buti M, Gane E, et al: Tenofovir disoproxil fumarate versus adefovir dipivoxil for chronic hepatitis B. N Engl J Med 2008;359:2442-2455.

58 Verhelst D, Monge M, Meynard JL, Fouqueray B, et al: Fanconi syndrome and renal failure induced by tenofovir: a first case report. Am J Kidney Dis 2002;40:1331-1333.

59 Lai KN, Tam JS, Lin HJ, Lai FM: The therapeutic dilemma of the usage of corticosteroid in patients with membranous nephropathy and persistent hepatitis B virus surface antigenaemia. Nephron 1990;54:12-17.

60 Cadrobbi P, Bortolotti F, Zacchello G, Rinaldi $R$, et al: Hepatitis $B$ virus replication in acute glomerulonephritis with chronic active hepatitis. Arch Dis Childhood 1985;60: 583-585. 
61 Lai FM, Tam JS, Li PK, Lai KN: Replication of hepatitis B virus with corticosteroid therapy in hepatitis B virus related membranous nephropathy. Virchows Archiv 1989;414: 279-284.

-62 Taskapan H, Oymak O, Dogukan A, Ozbakir O, et al: Transformation of hepatitis B virus-related membranous glomerulonephritis to crescentic form. Clin Nephrol 2000;54:161-163.

63 Guillevin L, Pagnoux C: Indications of plasma exchanges for systemic vasculitides. Ther Apher Dial 2003;7:155-160.

64 Guillevin L, Lhote F, Jarrousse B, Bironne P, et al: Polyarteritis nodosa related to hepatitis $B$ virus. A retrospective study of 66 patients. Ann Med Intern 1992;143(suppl 1):63-74.

-65 Fervenza FC, Abraham RS, Erickson SB, Irazabal MV, et al: Rituximab therapy in idiopathic membranous nephropathy: a 2-year study. Clin J Am Soc Nephrol 2010;5:21882198.
66 Stone JH, Merkel PA, Spiera R, Seo P, et al: Rituximab versus cyclophosphamide for ANCA-associated vasculitis. N Engl J Med 2010;363:221-232

67 Zhang B, Wang J, Xu W, Wang L, et al: Fatal reactivation of occult hepatitis $B$ virus infection after rituximab and chemotherapy in lymphoma: necessity of antiviral prophylaxis. Onkologie 2010;33:537-539.

68 Evens AM, Jovanovic BD, Su YC, Raisch DW, et al: Rituximab-associated hepatitis B virus (HBV) reactivation in lymphoproliferative diseases: meta-analysis and examination of FDA safety reports. Ann Oncol, Epub ahead of print.

69 Koo YX, Tan DS, Tan IB, Tao M, et al: Hepatitis $B$ virus reactivation in a patient with resolved hepatitis $B$ virus infection receiving maintenance rituximab for malignant B-cell lymphoma. Ann Intern Med 2009;150:655656.

70 Ozgonenel B, Moonka D, Savasan S: Fulminant hepatitis B following rituximab therapy in a patient with Evans syndrome and large B-cell lymphoma. Am J Hematol 2006;81: 302.
71 Matsue K, Kimura S, Takanashi Y, Iwama K, et al: Reactivation of hepatitis $B$ virus after rituximab-containing treatment in patients with CD20-positive B-cell lymphoma. Cancer 2010;116:4769-4776.

72 Xunrong L, Yan AW, Liang R, Lau GK: Hepatitis $B$ virus (HBV) reactivation after cytotoxic or immunosuppressive therapy pathogenesis and management. Rev Med Virol 2001;11:287-299.

73 Hamada T, Kumashiro R, Koga Y, Hino T, et al: Fatal acute hepatitis B virus infection while receiving immunosuppressants after renal transplantation. Intern Med 1993;32: 547-551.

74 Lai MK, Huang CC, Chu SH, Chuang CK, et al: Renal transplantation in hepatitis $\mathrm{B}$ carriers: comparison of azathioprine- and cyclosporine-treated recipients. Clin Transplants 1989;281-286.

-75 Liaw YF, Sung JJ, Chow WC, Farrell G, et al: Lamivudine for patients with chronic hepatitis $\mathrm{B}$ and advanced liver disease. N Engl J Med 2004;351:1521-1531.

\title{
Editorial Comment
}

\author{
Meguid El Nahas, Sheffield
}

The review of Elewa and colleagues highlights issues related to the association between HBV infection and nephropathies. This includes the possible fortuitous association between chronic HBV infections in endemic areas and the new onset of a nephropathy, as well as coinfections with other viruses such as HCV and HIV. The review informs the reader of the scope of antiviral therapies currently available to treat HBV including interferon- $\alpha$, nucleoside/nucleotide analogues (lamivudine, adefovir, entecavir, tenofovir, and telbivudine) and emtricitabine. The authors note that the beneficial effect of antiviral therapy in patients with $\mathrm{HBV}$-mediated glomerulonephritis has so far only been demonstrated with lamivudine. Of note, most published treatment data range from anecdotal reports to small and poorly controlled studies, hence the call for well-designed randomized controlled trials of antiviral therapy in patients with HBV-associated nephropathies. 